\title{
Gambaran Korban Meninggal Dunia dengan Cedera Kepala pada Kecelakaan Lalu Lintas di Bagian Forensik RSUP Dr. M. Djamil Padang Tahun 2018-2019
}

\author{
Muhammad Imam Arrasyid ${ }^{1}$, Rika Susanti' ${ }^{2}$, Roza Mulyana ${ }^{3}$ \\ ${ }^{1}$ Profesi Dokter Fakultas Kedokteran Universitas Andalas \\ ${ }^{2}$ Bagian Forensik Fakultas Kedokteran Universitas Andalas/RSUP Dr. M. DJamil Padang \\ ${ }^{3}$ Bagian Penyakit Dalam Fakultas Kedokteran Universitas Andalas/ RSUP Dr. M. DJamil Padang/Rumah Sakit Universitas Andalas
} A B S T R A C T

\begin{abstract}
Latar Belakang. Kecelakaan lalu lintas adalah suatu peristiwa di jalan yang tidak disengaja melibatkan kendaraan dengan atau tanpa pengguna jalan lain yang mengakibatkan korban manusia dan/atau kerugian harta benda. Cedera yang paling banyak terjadi pada saat kecelakaan lalu lintas adalah cedera kepala yang merupakan penyebab utama disabilitas dan mortalitas di negara berkembang.
\end{abstract}

Objektif. Untuk menganalisis gambaran korban meninggal dunia dengan cedera kepala pada kecelakaan lalu lintas di Bagian Forensik DR. M. Djamil Padang Tahun 2018-2019.

Metode. Jenis penelitian ini adalah deskriptif retrospektif. Pengambilan sampel dilakukan dengan teknik total sampling di Bagian Forensik RSUP Dr. M. Djamil Padang dari Maret 2020 September 2020.

Hasil. Hasil penelitian didapatkan korban meninggal dunia dengan cedera kepala pada kecelakaan lalu lintas sebanyak 105 orang. Pada usia paling banyak 15-29 tahun dan pada jenis kelamin lebih banyak laki-laki. Pola perlukaan paling adalah luka lecet. Regio kepala yang paling banyak terkena adalah regio frontalis. Waktu kecelakaan paling banyak pada jam 12.01-18.00 WIB dan hari kecelakaan paling banyak pada hari Minggu. Lokasi kecelakaan paling banyak di luar Kota Padang, jenis kendaraan paling banyak adalah sepeda motor, peran korban paling banyak adalah pengendara, dan jenis kecelakaan paling banyak adalah ditabrak oleh kendaraan lain.

Kesimpulan. Usia paling banyak 15-29 tahun dan jenis kelamin lebih banyak laki-laki . Regio kepala yang paling banyak terkena adalah regio frontalis. Lokasi kecelakaan paling banyak di luar Kota Padang, jenis kendaraan paling banyak adalah sepeda motor, peran korban paling banyak adalah pengendara, dan jenis kecelakaan paling banyak adalah ditabrak oleh kendaraan lain.

Kata kunci. gambaran korban meninggal, cedera kepala, kecelakaan lalu lintas
Background. A traffic accident is an incident on the road which accidentally involves a vehicle with or without other road users which results in human casualties and/or property loss. The most common injury that occurs during traffic accidents is head injury. Head injury due to traffic accidents is a major cause of disability and mortality in developing countries.

Objective. To analyze the overview of victim who died with head injury in traffic accidents at the forensic department of DR. M. Djamil Padang 2018-2019.

Methods. This type of research is retrospective descriptive. Sampling was carried out by total sampling technique in the forensic department of RSUP Dr. M. Djamil Padang from March 2020 - September 2020.

Results The results showed that 150 victims who died with head injury in traffic accidents. The conclusion of this study, most of the age is 15-29 years and the incidence was higher in males. The most common injury patterns are abrasions. The head region most affected is the frontalis region. The most time for accidents is at 12.01-18.00 WIB and the most accident days are on Sundays. Most of the accident locations were outside the city of Padang, most types of vehicles were motorbikes, the role of the most victims were motorists and the most types of accidents were being hit by other vehicles. Conclusion. Most of the age is 15-29 years and the incidence was higher in males. The head region most affected is the frontalis region. Most of the accident locations were outside the city of Padang, most types of vehicles were motorbikes, the role of the most victims were motorists and the most types of accidents were being hit by other vehicles.

Keyword: description of dead victims, head injuries, traffic accidents 
Apa yang sudah diketahui tentang topik ini?

Cedera yang paling banyak terjadi pada saat kecelakaan lalu lintas adalah cedera kepala. Cedera kepala akibat kecelakaan lalu lintas merupakan penyebab utama disabilitas dan mortalitas di negara berkembang.
Apa yang ditambahkan pada studi ini?

Analisis gambaran korban meninggal dunia dengan

cedera kepala pada kecelakaan lalu lintas di Bagian

Forensik DR. M. Djamil Padang Tahun 2018-2019.

CORRESPONDING AUTHOR

Phone: 082285014408

E-mail: arrasyidimam@yahoo.com

ARTICLE INFORMATION

Received: November $10^{\text {th }}, 2020$

Revised: July $29^{\text {th }}, 2021$

Available online: July $30^{\text {th }}, 2021$

\section{Metode}

Jenis penelitian ini adalah deskriptif retrospektif. Pengambilan sampel dilakukan dengan teknik total sampling menggunakan instrumen data sekunder. Sampel yang diambil dari penelitian ini adalah semua kasus korban meninggal dunia cedera kepala pada kecelakaan lalu lintas yang terjadi pada tahun 2018-2019 yang berjumlah 105 orang. Penelitian dilakukan di Bagian Forensik RSUP Dr. M. Djamil Padang dari Maret 2020 - September 2020. Populasi penelitian ini adalah seluruh korban yang meninggal dunia dengan cedera kepala pada kecelakaan lalu lintas berdasarkan hasil pemeriksaan di Rumah Sakit Umum Padang M. Djamil Kota Padang yang terjadi pada tahun 2018-2019. Penelitian ini sudah lolos kaji etik dengan nomor surat 257/KEPK/2020.

\section{Hasil}

Semua data yang diperoleh diolah secara manual dan disajikan dalam bentuk tabel. Jumlah pasien yang memenuhi kriteria inklusi dan eksklusi pada periode Januari 2018 - Desember 2019 sebanyak 105 orang. seluruh kejadian di kota Padang yang sering terjadi kecelakaan adalah jalan Bypass, jalan Raya Indarung, jalan Adinegoro, jalan Dr. Soetomo dan jalan Lubuk Begalung. ${ }^{4}$

Mengingat terjadinya peningkatan jumlah kejadian kecelakaan lalu lintas dari tahun 2018 ke 2019 dan cedera kepala merupakan penyebab kematian terbanyak dalam kecelakaan lalu lintas, serta belum adanya data spesifik mengenai gambaran cedera kepala pada kecelakaan lalu lintas di Bagian Forensik RSUP Dr. M. Djamil Padang, membuat penulis ingin meneliti dan menghasilkan salah satu sumber informasi kepada masyarakat maupun bagi penelitian selanjutnya.

\section{Usia dan Jenis Kelamin Korban Meninggal Dunia dengan Cedera Kepala pada Kecelakaan Lalu Lintas}

Hasil pada tabel 1 menunjukkan angka kejadian cedera kepala berdasarkan usia paling banyak usia 15-19 tahun (35,2\%), dan paling sedikit usia 70 tahun keatas $(4,8 \%)$. Karakteristik pasien cedera kepala berdasarkan jenis kelamin lebih banyak pada laki-laki (70,5\%), sedangkan pada perempuan sebesar $(29,5 \%)$. 
Tabel 1 Distribusi korban meninggal dunia dengan cedera kepala pada kecelakaan lalu lintas berdasarkan usia dan jenis kelamin

\begin{tabular}{lcc}
\multicolumn{1}{c}{ Karakteristik } & $\boldsymbol{f}$ & $\mathbf{\%}$ \\
\hline Usia & & \\
0 - 14 tahun & 18 & 17,1 \\
15 - 29 tahun & 37 & 35,2 \\
30 - 44 tahun & 12 & 11,4 \\
45 - 69 tahun & 33 & 31,5 \\
$\geq 70$ tahun & 5 & 4,8 \\
Total & 105 & 100 \\
Jenis Kelamin & & \\
Laki-laki & 74 & 70,5 \\
Perempuan & 31 & 29,5 \\
Total & 105 & 100 \\
\hline
\end{tabular}

\section{Pola Perlukaan Korban Meninggal Dunia dengan Cedera Kepala pada Kecelakaan Lalu Lintas}

Tabel 2 Distribusi frekuensi korban meninggal dunia dengan cedera kepala pada kecelakaan lalu lintas berdasarkan pola perlukaan

\begin{tabular}{lcc}
\hline \multicolumn{1}{c}{ Pola Perlukaan } & $\boldsymbol{f}$ & \% \\
\hline Luka Lecet & 23 & 21,9 \\
Luka Memar & 5 & 4,8 \\
Luka Robek & 17 & 16,2 \\
Luka Lecet dan Luka Memar & 16 & 15,2 \\
Luka Lecet dan Luka Robek & 15 & 14,3 \\
Luka Memar dan Luka Robek & 8 & 7,6 \\
Luka Lecet, Luka Memar, dan & 16 & 15,2 \\
Luka Robek & 5 & 4,8 \\
Tidak ditemukan Luka & 105 & 100 \\
Total & & \\
\hline
\end{tabular}

Hasil pada tabel 2 menunjukkan pola perlukaan yang paling banyak yaitu luka lecet $(21,9 \%)$, diikuti dengan luka robek $(16,2 \%)$, dan paling sedikit luka memar dan tidak ditemukan luka $(4,8 \%)$.

\section{Regio Kepala Korban Meninggal Dunia dengan Cedera Kepala pada Kecelakaan Lalu Lintas Berdasarkan}

Hasil pada tabel 3 menunjukkan regio kepala yang paling banyak terkena cedera kepala yaitu regio frontalis $(26,8 \%)$, selanjutnya regio orbitalis $(19,9 \%)$, diikuti dengan regio temporalis $(13,8 \%)$, dan paling sedikit pada regio zygomatical $(0,8 \%)$.
Tabel 3 Distribusi frekuensi korban meninggal dunia dengan cedera kepala pada kecelakaan lalu lintas berdasarkan regio kepala

\begin{tabular}{lcc}
\hline \multicolumn{1}{c}{ Regio Kepala } & $\boldsymbol{f}$ & $\mathbf{\%}$ \\
\hline Frontalis & 66 & 26,8 \\
Orbitalis & 49 & 19,9 \\
Nasalis & 19 & 7,7 \\
Oralis & 15 & 6,1 \\
Mentalis & 14 & 5,7 \\
Buccalis & 33 & 13,4 \\
Zygomatical & 2 & 0,8 \\
Temporalis & 34 & 13,8 \\
Parietalis & 3 & 1,2 \\
Occipitalis & 6 & 2,4 \\
Tidak Ada & 5 & 2,0 \\
Total & 246 & 100 \\
\hline
\end{tabular}

\section{Waktu dan Hari Kecelakaan Korban Meninggal Dunia dengan Cedera Kepala pada Kecelakaan Lalu Lintas}

Tabel 4 Distribusi frekuensi korban meninggal dunia dengan cedera kepala pada kecelakaan lalu lintas berdasarkan waktu dan hari kecelakaan

\begin{tabular}{lcc}
\hline \multicolumn{1}{c}{ Variabel } & $\boldsymbol{f}$ & \% \\
\hline Waktu (WIB) & & \\
$06.01-12.00$ & 24 & 22,9 \\
$12.01-18.00$ & 38 & 36,2 \\
$18.01-00.00$ & 35 & 33,3 \\
$00.01-06.00$ & 8 & 7,6 \\
Total & 105 & 100 \\
Hari & & \\
Senin & 14 & 13,3 \\
Selasa & 13 & 12,4 \\
Rabu & 13 & 12,4 \\
Kamis & 16 & 15,2 \\
Jum'at & 12 & 11,4 \\
Sabtu & 13 & 12,4 \\
Minggu & 24 & 22,9 \\
Total & 105 & 100 \\
\hline
\end{tabular}

Hasil pada tabel 4 menunjukkan frekuensi waktu kecelakaan paling banyak pada pukul 12.01-18.00 WIB $(36,2 \%)$ dan paling sedikit pada pukul 00.01-06.00 WIB (7,6\%). Frekuensi hari kecelakaan paling banyak terjadi pada hari Minggu $(22,9 \%)$, dan paling sedikit terjadi pada hari Jum'at $(11,4 \%)$. 
5. Lokasi Kecelakaan, Jenis Kendaraan, dan

Peran Korban pada Korban Meninggal Dunia dengan Cedera Kepala pada Kecelakaan Lalu Lintas

Tabel 5 Distribusi frekuensi korban meninggal dunia dengan cedera kepala pada kecelakaan lalu lintas berdasarkan lokasi kecelakaan, jenis kendaraan, dan peran korban

\begin{tabular}{lcc}
\hline \multicolumn{1}{c}{ Variabel } & $\boldsymbol{f}$ & \% \\
\hline Lokasi Kecelakaan & & \\
Kota Padang & 23 & 21,9 \\
Luar Kota Padang & 82 & 78,1 \\
Total & 105 & 100 \\
Jenis Kendaraan & & \\
Sepeda motor & 78 & 74,3 \\
Mobil & 6 & 5,7 \\
Pejalan Kaki & 21 & 20 \\
Total & 105 & 100 \\
Peran Korban & & \\
Pengendara & 63 & 60 \\
Penumpang & 21 & 20 \\
Pejalan Kaki & 21 & 20 \\
Total & 105 & 100 \\
\hline
\end{tabular}

Hasil pada tabel 5 menunjukkan frekuensi lokasi kecelakaan lebih banyak terjadi di luar kota padang $(78,1 \%)$, dibandingkan di kota padang (21,9\%). Hasil pada tabel ini juga menunjukkan frekuensi jenis kendaraan paling banyak sepeda motor $(74,3 \%)$, diikuti dengan pejalan kaki $(20 \%)$, dan paling sedikit mobil (5,7\%). Pada frekuensi peran korban saat kecelakaan paling banyak dialami oleh pengendara (60\%), dan paling sedikit dialami oleh penumpang dan pejalan kaki (20\%).

\section{Jenis Kecelakaan Korban Meninggal Dunia dengan Cedera Kepala pada Kecelakaan Lalu Lintas}

Tabel 6 Distribusi Penderita Anemia Aplastik Berdasarkan Luaran Kesembuhan

\begin{tabular}{lcc}
\hline \multicolumn{1}{c}{ Jenis Kecelakaan } & $\boldsymbol{f}$ & $\mathbf{\%}$ \\
\hline Bertabrakan dengan kendaraan lain & 12 & 11,4 \\
Menabrak kendaraan lain & 6 & 5,7 \\
Ditabrak oleh kendaraan lain & 58 & 55,2 \\
Jatuh Sendiri & 29 & 27,6 \\
Total & 105 & 100 \\
\hline
\end{tabular}

Hasil pada tabel 6 menunjukkan frekuensi jenis kecelakaan paling banyak ditabrak oleh kendaraan lain $(55,2 \%)$, dan paling sedikit menabrak kendaraan lain $(5,7 \%)$.

\section{Pembahasan}

Hasil penelitian ini menunjukkan korban cedera kepala pada kecelakaan lalu lintas paling banyak yaitu usia 15-29 tahun (35,2\%), dan paling sedikit yaitu diatas 70 tahun $(4,8 \%)$. Hal ini dapat disebabkan mobilitas yang tinggi pada kelompok usia produktif. Pada usia tersebut biasanya sudah dapat mengendarai kendaraan bermotor, tetapi belum disiplin dalam berkendara sehingga dapat menyebabkan kecelakaan lalu lintas. ${ }^{5}$

Hasil penelitian ini juga tidak jauh berbeda dengan penelitian Munthe et al., bahwa persentasi jumlah cedera kepala pada korban meninggal akibat kecelakaan lalu lintas paling banyak terjadi pada usia 21-30 tahun sebesar $(21,66 \%)$. Ratarata di usia ini menjadi tulang punggung keluarga sehingga lebih sering berada diluar rumah ataupun di jalan yang akan meningkatkan risiko terjadinya kecelakaan lalu lintas pada diri mereka. ${ }^{6}$

Pengendara yang lebih muda mungkin memiliki pengalaman yang lebih sedikit dalam mengendarai kendaraan bermotor. Penyebab lain seperti pengendara yang lebih muda melakukan peningkatan performa mesin kendaraan bermotornya secara ilegal dan tidak sesuai dengan standar. Modifikasi ini dapat meningkatkan risiko tabrakan karena kecepatan berkendara yang lebih tinggi. ${ }^{7}$

Pada umumnya pengendara yang lebih tua lebih berhati-hati di jalan, tetapi mereka lebih rentan secara fisik. Beberapa laporan pemerintah dan studi ilmiah juga menyebutkan bahwa usia lanjut mungkin memiliki risiko yang lebih tinggi untuk menderita cedera parah dan kematian. ${ }^{7}$

Hasil penelitian ini juga menunjukkan korban cedera kepala pada kecelakaan lalu lintas berdasarkan jenis kelamin lebih banyak terjadi pada laki-laki (70,5\%), daripada perempuan $(29,5 \%)$. Hal ini dikarenakan populasi laki-laki lebih besar dari pada perempuan, dan laki-laki dewasa dituntut untuk mencari nafkah di rumah, sehingga laki-laki ialah objek terbanyak dalam menggunakan jalan raya khususnya dalam berlalu lintas. ${ }^{8}$

Hal ini sejalan dengan penelitian Kepel et al. yang menyatakan jumlah korban kasus kecelakaan lalu lintas didominasi oleh laki-laki, 
disebabkan pengendara laki-laki usia muda mempunyai kecenderungan untuk melakukan pelanggaran terhadap peraturan lalu lintas. ${ }^{9}$

Pada laki-laki mudah timbul rasa marah pada saat berkendara yang mengakibatkan perilaku berkendara agresif dan berisiko munculnya kecelakaan dalam berkendara. ${ }^{10}$ Hasil penelitian ini juga sesuai dengan penelitian yang dilakukan Riyadina et al. yaitu distribusi korban kecelakaan lalu lintas didominasi oleh laki-laki karena kebanyakan laki-laki lebih sering beraktivitas di luar rumah untuk bekerja sehingga meningkatkan risiko terjadinya cedera akibat kecelakaan lalu lintas. $^{11}$

Hasil pada tabel distribusi korban meninggal dunia dengan cedera kepala pada kecelakaan lalu lintas berdasarkan pola perlukaan menunjukkan pola perlukaan yang paling banyak yaitu luka lecet $(21,9 \%)$ dan paling sedikit yaitu luka memar dan tidak ditemukan luka (4,8\%).

Pada kecelakaan lalu lintas sepeda motor sering terjadi luka lecet karena ketika terjatuh biasanya pengendara ataupun penumpang akan terseret disebabkan gaya tolak, gesekan antara aspal dengan kulit akan menghasilkan luka lecet pada bagian yang berkontak langsung. ${ }^{12}$

Luka lecet adalah jenis cedera yang paling umum di antara cedera eksternal dalam cedera kepala pada lalu lintas. Situs umum untuk cedera adalah wajah. ${ }^{7}$ Bagaimanapun juga sabuk pengaman dapat menyebabkan cedera, cedera ini biasanya dapat berupa luka lecet kecil dan luka memar di dada, bila tanpa sabuk pengaman cedera akan lebih menjadi parah. ${ }^{13}$

Pada penelitian ini didapatkan regio kepala yang paling banyak terkena cedera kepala yaitu regio frontalis $(26,8 \%)$, dan paling sedikit pada regio zygomatical $(0,8 \%)$. Penelitian yang sama dilakukan oleh Rahmi et al. yang menyatakan lokasi luka terbanyak terdapat di regio frontalis et orbitalis dan patah tulang terbanyak adalah os. frontal $(19,40 \%) .14$

Regio frontalis dan parietal dianggap sebagai situs anatomi kepala yang paling umum terjadinya laserasi dan hematoma kulit. Hal ini diduga akibat tingkat kecembungan tulang tengkorak di regio tersebut memudahkan terjadinya cedera kulit akibat trauma. 15

Terdapat cedera pada wajah, kepala, dan leher yang lebih tinggi dalam penelitian ini. Penjelasan yang mungkin adalah bahwa penumpang kendaraan bermotor tidak menggunakan sabuk pengaman, mengakibatkan sentakan ke depan selama tabrakan dan tingkat cedera yang lebih tinggi. ${ }^{7}$

Hasil pada penelitian ini menunjukkan frekuensi waktu kecelakaan paling banyak terjadi pada jam 12.01-18.00 (36,2\%) , dan paling sedikit pada jam 00.01-06.00 (7,6\%).

Mayoritas kecelakaan lalu lintas jalan terjadi pada siang hari. Hal ini dapat membenarkan fakta bahwa pada siang hari, terdapat peningkatan aktivitas manusia serta peningkatan kepadatan lalu lintas yang bisa menyebabkan kecelakaan lalu lintas jalan raya. Mengetahui waktu terjadinya kecelakaan pada korban kecelakaan lalu lintas di jalan raya penting untuk strategi preventif. 16

Frekuensi hari kecelakaan paling banyak terjadi di hari Minggu (22,9\%), dan paling sedikit terjadi pada hari Jum'at $(11,4 \%)$. Hal ini berkaitan dengan volume lalu lintas kendaraaan yang lewat di titik tertentu selama selang waktu tertentu. Varian hari dapat dikelompokkan menjadi hari kerja yaitu hari Senin - Jum'at, dan akhir pekan yaitu hari Sabtu dan Minggu. Pada akhir pekan yang juga merupakan hari libur bekerja sehingga kondisi ini dimanfaatkan untuk berpergian menyebabkan lalu lintas menjadi lebih padat dari hari kerja. ${ }^{17}$

Hasil pada penelitian ini menunjukkan frekuensi lokasi kecelakaan lebih banyak terjadi di luar kota Padang $(78,1 \%)$ dibandingkan di kota Padang sebesar 21,9\%. Hal ini dapat dikarenakan di kota Padang mempunyai daerah rawan kecelakaan lebih sedikit daripada diluar kota Padang dan pada daerah luar kota Padang juga merupakan jalan perlintasan antar kota dan provinsi. ${ }^{18}$

Hasil ini berkaitan dengan RSUP DR. M. Djamil Padang sebagai Rumah Sakit Pusat Rujukan Nasional berdasarkan Keputusan Menteri Kesehatan No. BN.06.01/I/874/2015 untuk wilayah Sumatera Bagian Tengah sehingga banyak korban meninggal dunia dengan cedera kepala pada kecelakaan lalu lintas dari luar kota Padang yang dirujuk ke rumah sakit ini. Kondisi ini terjadi karena RSUP Dr. M. Djamil sebagai rumah sakit rujukan memiliki fasilitas dan alat yang lebih lengkap dibandingkan dengan rumah sakit yang berada di daerah sehingga dapat dilakukan penanganan yang maksimal. ${ }^{19}$ 
Mayoritas kecelakaan terjadi di jalan raya nasional antar kota. Hal ini dapat dijelaskan dengan fakta bahwa jalan raya nasional merupakan jalan tersibuk dengan kendaraan yang melaju dengan kecepatan tinggi, jalan yang kurang lebar, banyak persimpangan, dan terdapat pembatas di sisi tengah. ${ }^{20}$

Frekuensi jenis kendaraan paling banyak pada sepeda motor $(74,3 \%)$, diikuti oleh tidak berkendara (20\%), dan paling sedikit pada mobil (5,7\%).Hal ini dapat dikarenakan jumlah kendaraan sepeda motor lebih banyak dibandingkan mobil, seperti yang dilaporkan oleh Kementerian Perhubungan dalam Buku Statistik Perhubungan 2016, data terakhir tahun 2016 jumlah sepeda motor di Indonesia tercatat sebanyak 106 ribu unit. Angka ini jauh lebih besar apabila dibandingkan dengan jumlah mobil yang hanya 21 ribu unit. ${ }^{21}$

Pengendara sepeda motor dengan cedera kepala berat lebih rentan meninggal di tempat kejadian karena mekanisme trauma energi tinggi dan tidak memakai helm pada saat berkendara mengakibatkan tidak ada perlindungan pada kepala saat mengalami benturan. $^{7}$

Cedera kepala berat pada pengendara sepeda motor yang dirawat di rumah sakit juga berisiko. Ketika trauma kepala parah yang awalnya selamat, pengendara sepeda motor berkemungkinan meninggal karena trauma berat lainnya setelah dirawat di rumah sakit. Dapat disimpulkan bahwa sebagian besar cedera kepala berat pada pengendara sepeda motor dapat dicegah dengan penggunaan helm pelindung. ${ }^{7}$

Hasil pada penelitian ini juga menunjukkan frekuensi peran korban pada saat kecelakaan paling banyak dialami oleh pengendara sebesar $60 \%$, sedangkan penumpang dan pejalan kaki didapatkan jumlah yang sama sebesar 20\%. Hal ini dapat terjadi karena pengendara tidak memakai helm, memakai helm yang tidak sesuai standar, tidak memakai sabuk pengaman, dan tidak mematuhi aturan lalu lintas. ${ }^{8}$ Berdasarkan penelitian oleh Ibrahim et al., sebagian besar faktor risiko pengendara yang mengalami kecelakaan disebabkan perilaku kurang waspada $(51,5 \%) .{ }^{22}$ Saat pengendara mempunyai tingkat kewaspadaan yang rendah, maka pengendara akan kesulitan dalam mengendalikan kendaraannya, sehingga risiko terjadinya kecelakaan lalu lintas akan meningkat. ${ }^{23}$

Beberapa penyebab terjadinya kecelakaan seperti pengguna jalan tidak memiliki pengetahuan yang memadai tentang penggunaan jalan yang benar, rambu lalu lintas tidak memadai, dan fitur pengurang kecepatan seperti speed bumps tidak selalu digunakan di lokasi yang tepat. ${ }^{20}$

Hasil pada penelitian ini menunjukkan frekuensi jenis kecelakaan paling banyak yang didapatkan yaitu ditabrak oleh kendaraan lain $(55,2 \%)$, dan paling sedikit menabrak kendaraan lain $(5,7 \%)$.

Hal ini berkaitan dengan pengendara yang kurang waspada menghadapi pengendara lain yang serampangan. ${ }^{24}$ Pengendara lain juga seringkali berkecepatan tinggi yang menyulitkan untuk mengendalikan kendaraannya sehingga risiko terjadi kecelakaan meningkat. ${ }^{23}$

Kelebihan dari penelitian ini adalah penelitian ini merupakan penelitian pertama untuk melihat gambaran korban meninggal dunia dengan cedera kepala pada kecelakaan lalu lintas di Bagian Forensik RSUP Dr. M. Djamil Padang. Variabel yang digunakan dalam penelitian ini spesifik sehingga data yang dihasilkan bersifat homogen. Kekurangan dari penelitian ini yaitu hanya meneliti korban yang dilakukan Visum et Repertum sehingga tidak dapat menggambarkan seluruh korban meninggal dengan cedera kepala pada kecelakaan lalu lintas di Bagian Forensik RSUP Dr. M. Djamil Padang.

\section{Simpulan}

Kesimpulan penelitian ini, pada usia paling banyak 15-29 tahun dan pada jenis kelamin lebih banyak laki-laki dibanding perempuan. Pola perlukaan paling adalah luka lecet. Regio kepala yang paling banyak terkena adalah regio frontalis. Waktu kecelakaan paling banyak pada jam 12.0118.00 WIB dan hari kecelakaan paling banyak pada hari Minggu. Lokasi kecelakaan paling banyak di luar Kota Padang, jenis kendaraan paling banyak adalah sepeda motor, peran korban paling banyak adalah pengendara, dan jenis kecelakaan paling banyak adalah ditabrak oleh kendaraan lain. Saran dari penelitian ini perlu dilakukan penelitian lanjutan terhadap variable yang belum diteliti seperti karakteristik pola perlukaan (jenis, lokasi, dan ukuran), dan 
pengaruh penggunaan alat keselamatan dalam berkendara dengan kejadian cedera kepala pada kecelakaan lalu lintas, serta perlu mencari total jumlah korban meninggal dunia dengan cedera kepala pada kecelakaan lalu lintas termasuk korban yang tidak dilakukan visum et repertum.

\section{Daftar Pustaka}

1. Undang Undang Republik Indonesia No. 22. 2009.

2. WHO. World Health Organization. Road Traffic Injuries: 2017.

3. Markam S, Atmadja D, Budijanto A. Cedera Kepala Tertutup. Jakarta: Balai Penerbit FK UI; 1999.

4. Badan Pusat Statistik. Jumlah Kecelakaan, Korban Mati, Luka Berat, Luka Ringan, dan Kerugian Materi yang Diderita Tahun 2018-2019. 2019.

5. Rambey, Pandani R. Karakteristik Penderita Cedera Kepala Akibat Kecelakaan Lalu Lintas yang Rawat Inap di RSUP H. Adam Malik Medan Tahun 2014 - 2015. Fak Kesehat Masy USU. 2016.

6. Munthe EN, Singh S, Nainggolan R. Gambaran Cedera Kepala Pada Korban Meninggal Akibat Kecelakaan Lalu Lintas Di Instalasi Kedokteran Forensik Dan Medikolegal RSUD Dr. Pirngadi Medan Tahun 2014-2015. Fak Kedokt Univ Methodist Indones. 2016.

7. Henry Alexander Leijdesdorff M, Bob Siegerink Ms, Cornelis Frederikus Maria Sier P, Martine Christina Bernadette Reurings P, Inger Birgitta Schipper, MD P. Injury pattern, injury severity, and mortality in 33,495 hospital-admitted victims of motorized two-wheeled vehicle crashes in The Netherlands. J Trauma. 2012;72(5):1365.

8. Lumandung FT, Siwu JF, Mallo JF. Gambaran Korban Meninggal Dengan Cedera Kepala Pada Kecelakaan Lalu Lintas Di Bagian Forensik BLU RSUP Prof. Dr. R. D. Kandou Manado Periode Tahun 2011- 2012. Fak Kedokt Univ Sam Ratulangi Manad. 2013.

9. Kepel FR, Mallo JF, Tomuka D. Pola Luka pada Kasus Kecelakaan Lalu Lintas di Bagian Ilmu Kedokteran Forensik dan Medikolegal RSUP Prof. Dr. R. D. Kandou Manado Periode Tahun 2017. J Biomedik. 2019;11:23-28.

10. C. Gerarghty J H, K S. Differential moderating effect of locus of control on effect of driving experience in young male and female drivers. Pers Indiv Differ. 2010;48:821-826.

11. W R, Suhardi, M P. Pola dan Determinan Sosiodemografi Cedera akibat Kecelakaan Lalu Lintas di Indonesia. MKI. 2009;59(10):464-472.

12. Lulie, Yohannes, Tri J. Analisis Hubungan Kecepatan dengan Tebal Helm yang Direkomendasikan. J Tek Sipil. 2006;6(2):171184.

13. Mahajan N, Aggarwal M, Raina S, Verma LR, Mazta SR, Gupta BP. Pattern of non-fatal injuries in road traffic crashes in a hilly area: A study from Shimla, North India. Int J Crit Illn Inj Sci. 2013;3(3):193.

14. Rahmi, W. Gambaran Cedera Kepala Korban Kecelakaan yang Dilakukan Pemeriksaan Luar Jenazah di Bagian Forensik RSUP Dr. M. Djamil Padang periode 1 Januari 1997 - 31 Desember 2000. Fak Kedokt Univ Andalas. 2002.
15. Aghakhani K, Heidari M, Ameri M, Mehrpisheh S, Memarian A. Characteristic of a traumatic brain injury among accident and falling down cases. Acta Med Iran. 2015;53(10):652-655.

16. Seid M, Azazh A, Enquselassie F, Yisma E. Injury characteristics and outcome of road traffic accident among victims at Adult Emergency Department of Tikur Anbessa specialized hospital, Addis Ababa, Ethiopia: a prospective hospital based study. BMC Emerg Med. 2015;15(10):8.

17. Rompis A, Mallo J, Tomuka D. Kematian Akibat Kecelakaan Lalu Lintas Kota Tomohon Tahun 2012. Fak Kedokt Univ Sam Ratulangi.

18. Stephane I, Saputra H, Karfindo, Jelita S. Sistem Informasi Geografis Titik Rawan Kecelakaan Daerah Sumatera Barat Berbasis Web. STMIK Indones Padang. 2018.

19. Direksi. Rencana Bisnis Anggaran Tahun 2020 RSUP Dr. M. Djamil Padang. 2019:2.

20. Hatamabadi H, Vafaee R, Haddadi M, Abdalvand A, Esnaashari H, Soori H. Epidemiologic Study of Road Traffic Injuries by Road User Type Characteristics and Road Environment in Iran: A Community-Based Approach. Taylor Fr. 2012;13(1):61-64.

21. Kementerian Perhubungan. Statistik Perhubungan 2016. Jakarta: Kementerian Perhubungan; 2016.

22. Ibrahim MM, Adi MS, Suhartono. Gambaran Distribusi Kejadian Kecelakaan Lalu Lintas pada Pengendara Sepeda Motor. J Ilm STIKES Kendal. 2018;8(2):82-91.

23. Sutalaksana IZ, Mahacandra M. Aktivitas Sekunder Audio untuk Menjaga Kewaspadaan Pengemudi Mobil Indonesia. J Jati Undip. 2012;7(3):185-190.

24. Supriyono S. Implementasi Traffic Accident Analysis Guna Menanggulangi Kecelakaan Lalu Lintas. Univ Diponegoro. 2010. 